\title{
A kinetic study of the mechanism of oxidation of arabinose, fructose and lactose by peroxydisulphate
}

\author{
M. J. A. Abualreish ${ }^{1,2 *}$, Abdallah Aissa ${ }^{2,3}$ \\ ${ }^{1}$ Department of Chemistry, Faculty of Science, Northern Borders University, Arar, Kingdom of Saudi Arabia (current address) \\ ${ }^{2}$ Department of Chemistry, Faculty of Science and Technology, Omdurman Islamic University, Sudan (permanent address) \\ ${ }^{3}$ Laboratoire of Physico-Chemical Materials, University of Monastir, IPEM-Monastir Tunisia \\ *Corresponding author_E-mail: Mustjeed_2008@hotmail.com
}

Copyright (1) 2015 M. J. A. Abualreish, Abdallah Aissa. This is an open access article distributed under the Creative Commons Attribution License, which permits unrestricted use, distribution, and reproduction in any medium, provided the original work is properly cited.

\begin{abstract}
The uncatalysed reactions of peroxydisulphate with $\mathrm{L}(-)$ arabinose, $\mathrm{D}(-)$ fructose and lactose ((called arabinose, fructose and lactose respectively, throughout this paper)) were investigated kinetically. The reactions were first order in peroxydisulphate and of fractional order in substrate concentrations. The kinetic nature is discussed and the rate law is deduced from a suggested mechanism.
\end{abstract}

Keywords: Kinetic; Arabinose; Fructose; Fractional Order; Lactose; Peroxydisulphate.

\section{Introduction}

Oxidation mechanism of both inorganic and organic substrates by peroxydisulphate has been reviewed by Wilmarth and Haim [1]. They found that peroxydisulphate oxidizes a variety of organic compounds, including alcohols, aldehydes, ketones, carbohydrates, phenols and amines and the majority of the oxidations proceed via free-radical chain mechanism, but a few are ionic in character namely the oxidations of phenols and aromatic amines.

The oxidation of some carbohydrates such as sucrose, rhamnose and dextrose were studied by Wood and Walker [2] in the presence of silver ion as catalyst and found that fairly concordant velocity constants for the oxidation of aldoses can be obtained and they concluded that aldoses were quantitatively converted to aldonic acids.

Vasudeva [3] studied the uncatalysed oxidation of $\mathrm{D}(+)$ glucose by peroxydisulphate and found the reaction to follow first order in peroxydisulphate ion and fractional order in glucose.

\section{Material and methods}

\subsection{Experimental}

All chemicals used were AnalaR grade. All solutions were prepared according to the usual analytical procedures. Deionized water was used in all kinetic runs. Since the reaction does not take place to any measurable extent at room temperature $\left(\mathrm{t}_{1 / 2}=\right.$ one month) [3], the range of temperature $60-80^{\circ} \mathrm{C}$ was used. The reaction vessel was a $250 \mathrm{ml}$. round bottom flask for all kinetic runs. The reaction vessel was cleaned after every experiment with soap, conc.HCl, deionized water and finally dried in the oven at $100^{\circ} \mathrm{C}[4]$.

\section{Results and discussion}

Tables 1(A), 2(A) and 3(A) include the initial rates and rate constants of the reactions of arabinose, fructose and lactose with peroxydisulphate at $60^{\circ} \mathrm{C}$. The concentration of each substrate was kept constant at $2 \times 10^{-2}$ mole/l and that of 
Peroxydisulphate was increased from $5 \times 10^{-3}$ to $8 \times 10^{-2}$ mole/l. Figures (A.1), (B.1) and (C.1) show that the plots of the initial rates (R) against $\left[\mathrm{S}_{2} \mathrm{O}_{8}=\right]_{\text {Aver }}$ the average concentrations are linear and satisfy the following equation:

$\mathrm{R}=\mathrm{k}_{\mathrm{O}}\left[\mathrm{S}_{2} \mathrm{O}_{8}=\right]_{\text {Aver }}$

In equation (1) $\mathrm{k}_{\mathrm{o}}$ is the observed rate constant of the reaction; and the values are given in table (4). Equation (1) show that the order of the reaction in peroxydisulphate is unity in each case .Figures (A.2), (B.2) and (C.2) (( data from tables 1(B), 2(B) and 3 (B) )) show that the initial rates of the reactions are dependent on the substrate concentration when raised to the power $\mathrm{O} .2$ ((varied from $2 \times 10^{-3}$ mole/l to $8 \times 10^{-2}$ mole/l $)$ ) at constant peroxydisulphate concentration of $2 \mathrm{X} 10^{-2} \mathrm{~mole} / \mathrm{l}$ at $60^{\circ} \mathrm{C}$.

Table 1: Rate $(\mathrm{R})$ and Rate Constant $\left(\mathrm{k}_{\mathrm{o}}\right)$ Data of the Arabinose Peroxydisulphate Reaction at $60^{\circ} \mathrm{C}$, All Concentrations are in Mole/L; $\mathrm{R}$ in Mole $\mathrm{L}^{-1} \mathrm{Sec}^{-1}$ and $\mathrm{k}_{\mathrm{o}}$ in $\left(\mathrm{Sec}^{-1}\right)$ Unit.

(A)

\begin{tabular}{lllllllll}
\hline $10^{3}\left[\mathrm{~S}_{2} \mathrm{O}_{8}{ }^{\circ}\right]_{\mathrm{o}}$ & 5 & 10 & 20 & 30 & 40 & 50 & 60 & 80 \\
\hline $10^{3}\left[\mathrm{~S}_{2} \mathrm{O}_{8}{ }^{\circ}\right]_{\text {aver }}$ & 3 & 6 & 15 & 23 & 31 & 41 & 47 & 65 \\
$10^{7} \mathrm{R}$ & 1.6 & 2.6 & 3.4 & 5.1 & 6.6 & 7.5 & 7.6 & 11.7 \\
$10^{5} \mathrm{k}_{\mathrm{o}}$ & 4.6 & 4.3 & 2.7 & 2.5 & 2.2 & 1.8 & 1.8 & 1.9 \\
\hline
\end{tabular}

[Arabinose $]=2 \mathrm{X} 10^{-2} \mathrm{~mole} / \mathrm{l}$

(B)

\begin{tabular}{lllllllll}
\hline $10^{3}\left[\mathrm{~S}_{2} \mathrm{O}_{8}\right]_{\text {aver }}$ & 14 & 14 & 13 & 15 & 13 & 12 & 12 & Mean \\
\hline $10^{3}[\text { Arabinose }]_{\mathrm{o}}$ & 2 & 5 & 10 & 20 & 40 & 50 & 80 & \\
{$[\text { Arabinose }]_{\mathrm{o}}^{0.2}$} & 0.29 & 0.35 & 0.40 & 0.46 & 0.53 & 0.55 & 0.60 & \\
$10^{7} \mathrm{R}$ & 4.2 & 4.0 & 5.8 & 3.4 & 5.5 & 5.4 & 5.9 & 4.88 \\
$10^{5} \mathrm{k}_{\mathrm{o}}$ & 3.8 & 3.3 & 3.9 & 2.7 & 3.9 & 4.9 & 4.1 & 3.8 \\
\hline
\end{tabular}

$\left[\mathrm{S}_{2} \mathrm{O}_{8}{ }^{\circ}\right]=2 \times 10^{-2} \mathrm{~mole} / \mathrm{l}$

Table 2: Rate $(\mathrm{R})$ and Rate Constant $\left(\mathrm{k}_{\mathrm{o}}\right)$ Data of the Fructose Peroxydisulphate Reaction At $60^{\circ} \mathrm{C}$ (Units as in Table (1)). (A)

\begin{tabular}{lllllllll}
\hline $10^{3}\left[\mathrm{~S}_{2} \mathrm{O}_{8}{ }^{\circ}\right]_{\mathrm{o}}$ & 5 & 10 & 20 & 30 & 40 & 50 & 60 & 80 \\
\hline $10^{3}\left[\mathrm{~S}_{2} \mathrm{O}_{8}{ }^{\circ}\right]_{\text {aver }}$ & 2 & 6 & 12 & 20 & 25 & 34 & 45 & 53 \\
$10^{7} \mathrm{R}$ & 3.1 & 2.8 & 6.2 & 7.1 & 10.0 & 11.7 & 12.5 & 20.9 \\
$10^{5} \mathrm{k}_{\mathrm{o}}$ & 16.9 & 4.6 & 5.2 & 3.6 & 4.2 & 3.7 & 2.8 & 3.8 \\
\hline
\end{tabular}

[Fructose $]=2 \times 10^{-2} \mathrm{~mole} / \mathrm{l}$

(B)

\begin{tabular}{lllllllll}
\hline $10^{3}\left[\mathrm{~S}_{2} \mathrm{O}_{8}\right]_{\text {aver }}$ & 13 & 11 & 10 & 12 & 10 & 8 & 8 & Mean \\
$0^{3}[\text { Fructose }]_{\mathrm{o}}$ & 2 & 5 & 10 & 20 & 40 & 50 & 80 & \\
{$[\text { Fructose }]_{\mathrm{o}}^{0.2}$} & 0.29 & 0.35 & 0.40 & 0.46 & 0.53 & 0.55 & 0.60 & \\
$10^{7} \mathrm{R}$ & 5.2 & 6.4 & 6.9 & 6.2 & 7.2 & 6.9 & 8.10 & 6.7 \\
$10^{5} \mathrm{k}_{\mathrm{o}}$ & 4.1 & 5.8 & 6.8 & 5.2 & 7.3 & 9.5 & 9.6 & 6.9 \\
\hline
\end{tabular}

Table 3: Rate $(\mathrm{R})$ and Rate Constant $\left(\mathrm{k}_{\mathrm{o}}\right)$ Data of the Lactose Peroxydisulphate Reaction at $60^{\circ} \mathrm{C}$ (Units as in Table (1)).

(A)

\begin{tabular}{llllllll}
\hline $10^{3}\left[\mathrm{~S}_{2} \mathrm{O}_{8}{ }^{\circ}\right]_{\mathrm{o}}$ & 10 & 20 & 30 & 40 & 50 & 60 & 80 \\
\hline $10^{3}\left[\mathrm{~S}_{2} \mathrm{O}_{8}{ }^{\circ}\right]_{\text {aver }}$ & 6 & 12 & 16 & 27 & 31 & 38 & 49 \\
$10^{7} \mathrm{R}$ & 3.2 & 5.8 & 9.6 & 10.1 & 13.8 & 13.4 & 19.9 \\
$10^{5} \mathrm{k}_{\mathrm{o}}$ & 5.6 & 4.9 & 5.7 & 3.8 & 4.5 & 4.4 & 4.5 \\
\hline
\end{tabular}

[Lactose $]=2 \mathrm{X} 10^{-2} \mathrm{~mole} / \mathrm{l}$

(B)

\begin{tabular}{lllllllll}
\hline $10^{3}\left[\mathrm{~S}_{2} \mathrm{O}_{8}\right]_{\text {aver }}$ & 15 & 12 & 13 & 12 & 12 & 11 & 13 & Mean \\
\hline $10^{3}[\text { lactose }]_{\mathrm{o}}$ & 2 & 5 & 10 & 20 & 40 & 50 & 80 & \\
{$[\text { lactose }]_{\mathrm{o}}^{0.2}$} & 0.29 & 0.35 & 0.40 & 0.46 & 0.53 & 0.55 & 0.60 & \\
$10^{7} \mathrm{R}$ & 3.8 & 5.3 & 5.3 & 5.8 & 6.1 & 6.4 & 6.1 & 5.5 \\
$10^{5} \mathrm{k}_{\mathrm{o}}$ & 2.4 & 4.4 & 4.3 & 4.9 & 5.6 & 5.9 & 4.9 & 4.6 \\
\hline
\end{tabular}

$\left[\mathrm{S}_{2} \mathrm{O}_{8}{ }{ }\right]=2 \times 10^{-2} \mathrm{~mole} / \mathrm{l}$ 


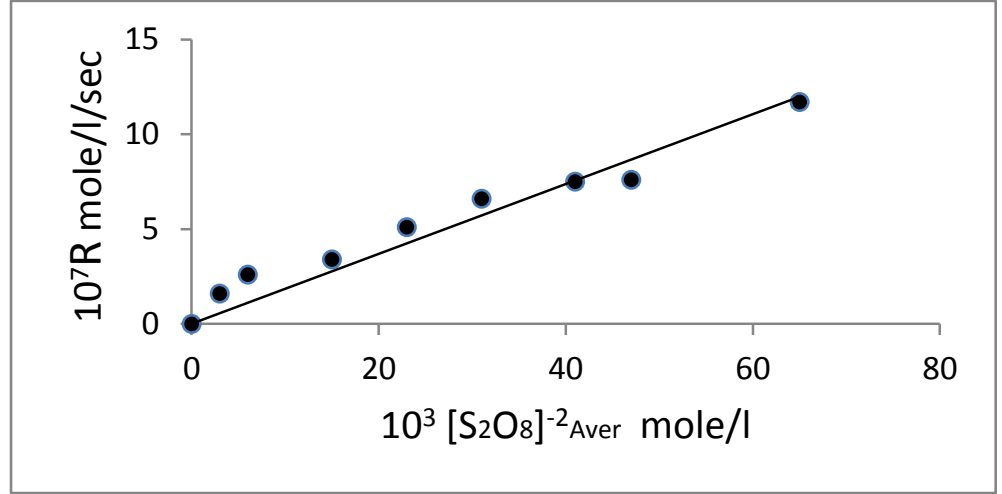

Fig (1.A) : Rate dependence on peroxydisulphate concentration at $60^{\circ} \mathrm{C}$

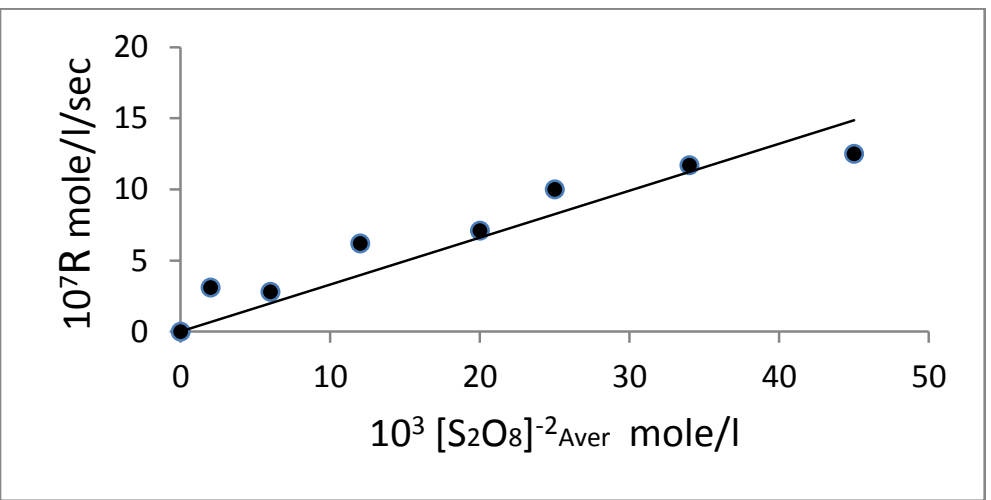

Fig (1.B): Rate dependence on peroxydisulphate concentration at $60^{\circ} \mathrm{C}$.

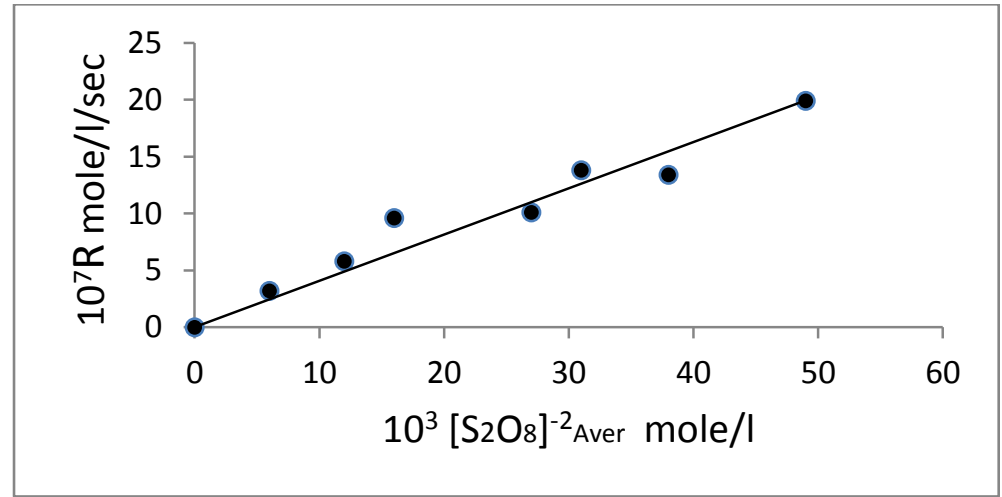

Fig (1.C): Rate dependence on peroxydisulphate concentration at $60^{\circ} \mathrm{C}$.

Table 4: The Observed Rate Constant $\mathrm{k}_{\mathrm{o}}$ for the Arabinose; Fructose and Lactose at $60^{\circ} \mathrm{C}$.

\begin{tabular}{lccc} 
& Table 4: The Observed Rate Constant $\mathrm{k}_{\mathrm{o}}$ for the Arabinose; Fructose and Lactose at $60^{\circ} \mathrm{C}$. & Lactose \\
\hline Substrate & Arabinose & Fructose & 4.60 \\
\hline $10^{5} \mathrm{k}_{\mathrm{o}} \mathrm{sec}^{-1}$ & 3.80 & 6.90 & \\
& & & \\
& Table 5: The Initial Rates R of Arabinose, Fructose and Lactose at $60^{\circ} \mathrm{C}$. & \\
\hline Substrate & Arabinose & Fructose & Lactose \\
\hline $10^{7} \mathrm{R} \mathrm{mole} \mathrm{l}^{-1} \mathrm{sec}^{-1}$ & 4.88 & 6.70 & 5.50 \\
\hline
\end{tabular}

* The values for the three substrates are different.

The data of tables (1), (2) and (3) for R show that the reaction is dependent on substrate concentrations when raised to the power of 0.2 for each of these reactions relation (2) applies. This shows that the order in arabinose, fructose and lactose is fractional.

$\mathrm{R}=\mathrm{k}[\text { Substrate }]^{0.2}$ 


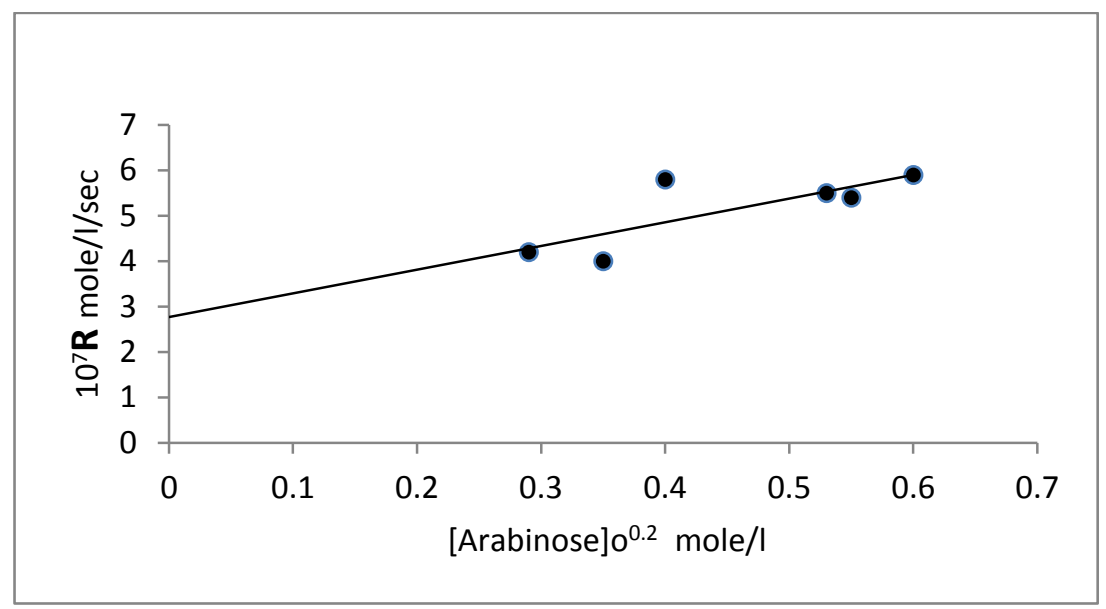

Fig (2.A): Plot of the rate against $[\text { Arabinose }]^{0.2}$ at $60^{\circ} \mathrm{C}$

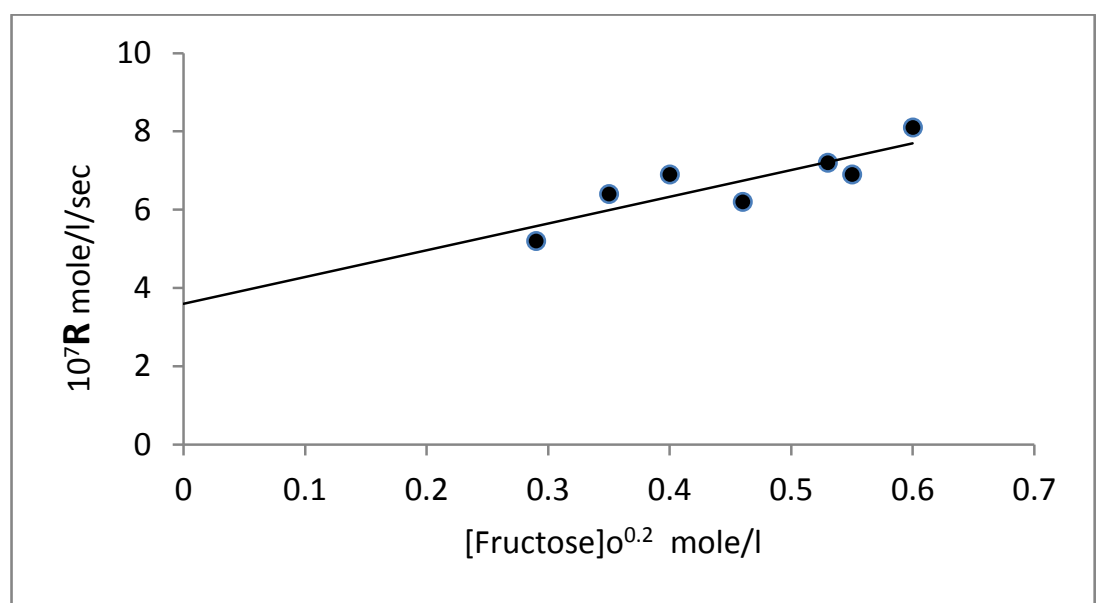

Fig (2.B): Plot of the rate against [Fructose $]^{0.2}$ at $60^{\circ} \mathrm{C}$.

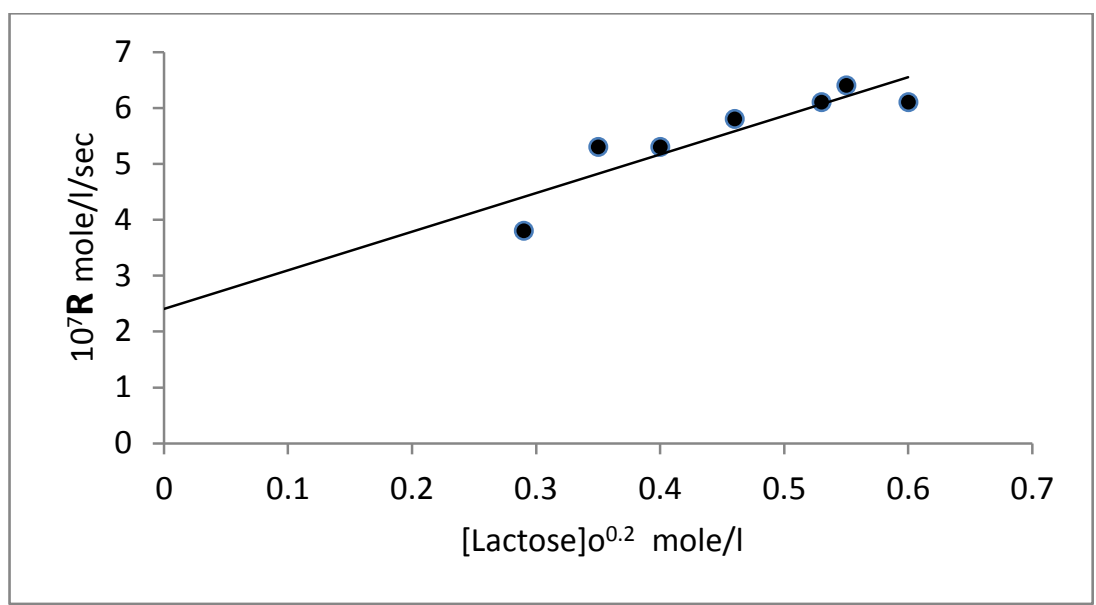

Fig (2.C): Plot of the rate against $[\text { Lactose }]^{0.2}$ at $60^{\circ} \mathrm{C}$.

During the present work the thermal decomposition of peroxydisulphate alone was studied and a value of $\mathrm{k}_{1}=1.09 \times 10^{-5}$ $\mathrm{sec}^{-1}$ and $\mathrm{R}^{\prime}=1.72 \times 10^{-7}$ mole $1^{-1} \mathrm{sec}^{-1}$ at $60{ }^{\circ} \mathrm{C}$ was found. $\left(2 \times 10^{-2}\right.$ mole $/ 1$ solution of peroxydisulphate was used) [5] .Figures (A.2), (B.2) and (4.C.5) cannot be used to obtain the rate of such reactions in absence of substrates. The conclusion drawn from a study of the glucose - peroxydisulphate reaction[3] was that peroxydisulphate decomposes thermally in absence as well as presence of glucose. This seems to be a general feature of peroxydisulphate reactions with organic substrates[1] . In order to reconcile these facts with equations (1) and (2), we shall consider the term $\mathrm{kO}$ of equation (1) to be composite and can be expressed by equation (3), where:

$\mathrm{k}_{\mathrm{O}}=\mathrm{k}_{1}+\mathrm{k}_{2}[\text { Substrate }]^{\mathrm{n}}$ 
$\mathrm{k}_{1}$ the rate constant of the thermal decomposition of peroxydisulphate alone in the absence of a substrate, $\mathrm{k}_{2}$ the bimolecular rate constant. Substituting the value of $\mathrm{k}_{\mathrm{o}}$ from equation (3) into equation (1) we get equation (4), and it may be taken to represent:

$-\mathrm{d}\left[\mathrm{S}_{2} \mathrm{O}_{8}=\right] / \mathrm{dt}=\mathrm{k}_{1}\left[\mathrm{~S}_{2} \mathrm{O}_{8}=\right]+\mathrm{k}_{2}\left[\mathrm{~S}_{2} \mathrm{O}_{8}=\right][\text { Substrate }]^{\mathrm{n}}$

The complete rate law for the reactions investigated in which $n=0.2$, as in equations (5) and (6) where $\mathrm{R}$ is the initial rate of the overall reaction.

$$
\begin{aligned}
& \mathrm{R}=\mathrm{k}_{1}\left[\mathrm{~S}_{2} \mathrm{O}_{8}=\right]+\mathrm{k}_{2}\left[\mathrm{~S}_{2} \mathrm{O}_{8}=\right][\text { Substrate }]^{\mathrm{n}} \\
& \mathrm{R}=\mathrm{R}^{\prime}+\mathrm{k}_{2}\left[\mathrm{~S}_{2} \mathrm{O}_{8}=\right][\text { Substrate }]^{\mathrm{n}}
\end{aligned}
$$

$\mathrm{R}^{\prime}$ is the initial rate of the thermal decomposition of peroxydisulphate, $\mathrm{k} 1$ and $\mathrm{K} 2$ were as given above (equation (3)). Equation (6) can be rearranged to take the form:

$$
\log \frac{\left[\mathrm{R}-\mathrm{R}^{\prime}\right]}{\left[\mathrm{S}_{2} \mathrm{O}_{8}=\right]}=\log \mathrm{k}_{2}+\mathrm{n} \log \text { [Substrate] }
$$

Through graphical representation according to this equation ((Figures (A.3), (B.3) and (C.3))) the values of K2 (from the intercept of the straight line) and $\mathrm{n}$ the order of the reaction with respect to substrate (from the slope of the same line) were computed.

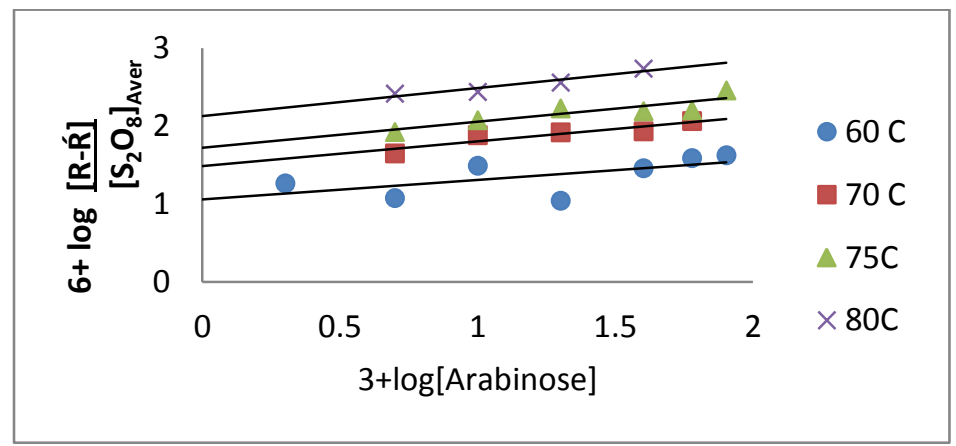

Fig (3.A): Confirmation of the reaction order for Arabinose over the range $60-80{ }^{\circ} \mathrm{C}$.

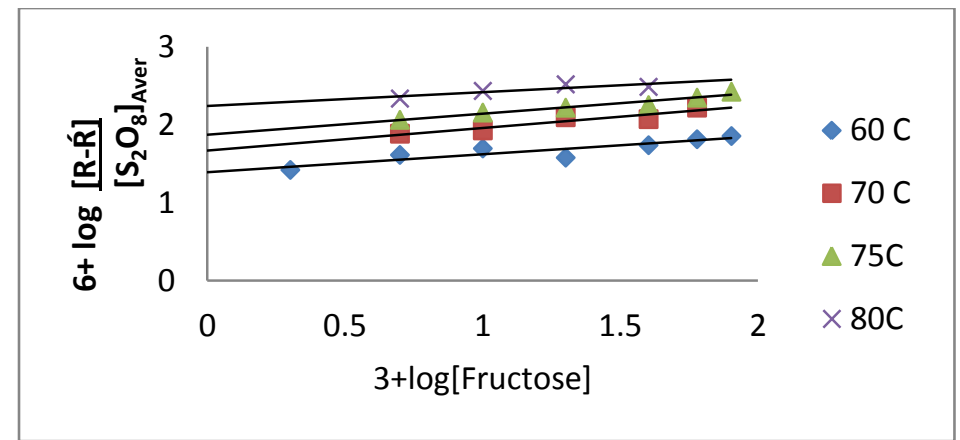

Fig (3.B): Confirmation of the reaction order for Fructose over the range $60-80^{\circ} \mathrm{C}$

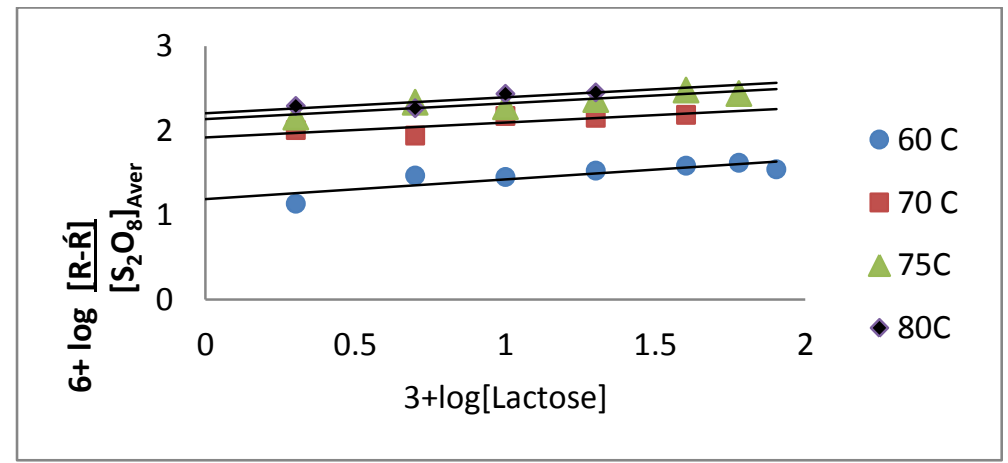

Fig (3.C): Confirmation of the reaction order for lactose over the range $60-80{ }^{\circ} \mathrm{C}$. 
Table 6: Values of $\mathrm{k}_{2}$ and $\mathrm{n}$ over the Temperature Range $60-80^{\circ} \mathrm{C}$ According to Equation (7).

\begin{tabular}{|c|c|c|c|c|}
\hline Temperature ${ }^{\circ} \mathrm{C}$ & 60 & 70 & 75 & 80 \\
\hline $\mathrm{n}$ & 0.21 & 0.20 & 0.20 & 0.22 \\
\hline $\mathrm{k}_{2} \mathrm{~L} \mathrm{~mole}^{-1} \sec ^{-1} 10^{5}$ & 3.55 & 10.39 & 12.12 & 38.31 \\
\hline \multicolumn{5}{|c|}{ (B) Fructose } \\
\hline Temperature ${ }^{\circ} \mathrm{C}$ & 60 & 70 & 75 & 80 \\
\hline $\mathrm{n}$ & 0.22 & 0.24 & 0.23 & 0.29 \\
\hline $\mathrm{k}_{2} \mathrm{~L} \mathrm{~mole}^{-1} \sec ^{-1} 10^{5}$ & 4.64 & 10.59 & 15.85 & 30.43 \\
\hline
\end{tabular}

\begin{tabular}{lllll} 
& & & & \\
\hline Temperature Lactose & & & \\
& & & & \\
& 60 & 70 & 05 & 80 \\
$\mathrm{k}_{2} \mathrm{~L} \mathrm{~mole}^{-1} \mathrm{sec}^{-1} 10^{5}$ & 0.21 & 0.23 & 0.25 & 0.20 \\
\end{tabular}

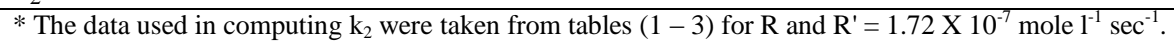

The nature of the reactions with peroxydisulphate:

The chain characteristics are observed in the effect of the shape of the reaction vessel on the observed rate constant [6].

This observation was confirmed by adding glass wool (5 grams), table (7).

Table 7: Effect of Added Glass Wool (At $60^{\circ} \mathrm{C}$ )

\begin{tabular}{llll}
\hline Substrate & Arabinose & Fructose & Lactose \\
\hline $10^{5} \mathrm{k}_{\mathrm{o}} \mathrm{sec}^{-1}$ & 2.69 & 5.19 & 4.91 \\
$10^{5} \mathrm{k}_{\mathrm{o}} \mathrm{sec}^{-1}$ & 5.26 & 8.75 & 8.51 \\
(glass wool ) & & &
\end{tabular}

$[$ Substrate $]=\left[\mathrm{S}_{2} \mathrm{O}_{8}{ }\right]=2 \mathrm{X} 10^{-2}$ mole $/ \mathrm{l}$

Moreover, the addition of ally acetate $(1 \mathrm{ml})$ to the reaction mixture (( allyl acetate being a free radical scavenger $))$ had an inhibiting effect table ( 8 ), such facts suggest that a free radical chain mechanism must be operative and confirm the chain characteristics[7].

Table 8: Effect of Allyl Acetate (At $60^{\circ} \mathrm{C}$ )

\begin{tabular}{llll}
\hline Substrate & Arabinose & Fructose & Lactose \\
\hline $10^{5} \mathrm{k}_{\mathrm{o}} \mathrm{sec}^{-1}$ & 2.69 & 5.19 & 4.91 \\
$10^{5} \mathrm{k}_{\mathrm{o}} \mathrm{sec}^{-1}$ & 1.21 & 3.75 & 3.43 \\
(allyl acetate ) & & & \\
\hline
\end{tabular}

$[$ Substrate $]=\left[\mathrm{S}_{2} \mathrm{O}_{8}{ }^{=}\right]=2 \times 10^{-2} \mathrm{~mole} / \mathrm{l}$

Temperature effect, Evaluation of $\mathrm{E}_{\mathrm{a}}$ for $\mathrm{k}_{\mathrm{o}}$ and $\mathrm{k}_{2}$ :

Table (9) includes the rate constants of arabinose (A), fructose (B), and lactose (C) with peroxydisulphate over the range $60-80^{\circ} \mathrm{C}$.

Table 9: Effect of Temperature:

(A) Arabinose

\begin{tabular}{llllllc}
\hline $\mathrm{T}^{\circ} \mathrm{K}$ & $\frac{10^{3}}{\mathrm{~T}} \mathrm{~K}^{\mathrm{O}-1}$ & $10^{5} \mathrm{k}_{\mathrm{o}} \mathrm{sec}^{-1}$ & $10^{5} \mathrm{k}_{1} \mathrm{sec}^{-1}$ & $10^{5} \mathrm{k}_{2} \mathrm{sec}^{-1}$ & $5+\log \mathrm{k}_{\mathrm{o}}$ & $5+\operatorname{logk} \mathrm{k}_{2}$ \\
\hline 333 & 3.003 & 2.69 & 1.09 & 3.55 & 0.4298 & 0.5502 \\
343 & 2.915 & 12.84 & 2.92 & 10.39 & 1.1085 & 1.0166 \\
348 & 2.874 & 34.39 & 6.82 & 12.12 & 1.5364 & 1.0835 \\
353 & 2.833 & 60.99 & 12.37 & 38.31 & 1.7853 & 1.5833 \\
\hline
\end{tabular}

Ea for $\mathrm{k}_{\mathrm{o}}=36.13 \mathrm{kcal} / \mathrm{mole}$

Ea for $\mathrm{k}_{2}=27.85 \mathrm{kcal} / \mathrm{mole}$

(B) Fructose

\begin{tabular}{|c|c|c|c|c|c|c|}
\hline $\mathrm{T}^{\mathrm{o}} \mathrm{K}$ & $\frac{10^{3}}{\mathrm{~T}} \mathrm{~K}^{\mathrm{O}-1}$ & $10^{5} \mathrm{k}_{\mathrm{o}} \sec ^{-1}$ & $10^{5} \mathrm{k}_{1} \sec ^{-1}$ & $10^{5} \mathrm{k}_{2} \mathrm{sec}^{-1}$ & $5+\log \mathrm{k}_{\mathrm{o}}$ & $5+\log \mathrm{k}_{2}$ \\
\hline 333 & 3.003 & 5.19 & 1.09 & 4.64 & 0.71517 & 0.6665 \\
\hline 343 & 2.915 & 14.27 & 2.92 & 10.59 & 1.1544 & 1.0249 \\
\hline 348 & 2.874 & 33.36 & 6.82 & 15.85 & 1.5232 & 1.2000 \\
\hline 353 & 2.833 & 53.01 & 12.37 & 30.43 & 1.7243 & 1.4833 \\
\hline
\end{tabular}

Ea for $\mathrm{k}_{\mathrm{o}}=28.24 \mathrm{kcal} / \mathrm{mole}$

Ea for $\mathrm{k}_{2}=25.38 \mathrm{kcal} /$ mole 
(C) Lactose

\begin{tabular}{llllllc}
\hline $\mathrm{T}^{\mathrm{o}} \mathrm{K}$ & $\frac{10^{3}}{\mathrm{~T}} \mathrm{~K}^{\mathrm{O}-1}$ & $10^{5} \mathrm{k}_{\mathrm{o}} \mathrm{sec}^{-1}$ & $10^{5} \mathrm{k}_{1} \mathrm{sec}^{-1}$ & $10^{5} \mathrm{k}_{2} \mathrm{sec}^{-1}$ & $5+\log \mathrm{k}_{\mathrm{o}}$ & $5+\operatorname{logk} \mathrm{k}_{2}$ \\
\hline 333 & 3.003 & 4.91 & 1.09 & 3.41 & 0.6911 & 0.5328 \\
343 & 2.915 & 20.22 & 2.92 & 12.12 & 1.3058 & 1.0833 \\
348 & 2.874 & 34.20 & 6.82 & 19.95 & 1.5340 & 1.2999 \\
353 & 2.833 & 45.77 & 12.37 & 28.18 & 1.6606 & 1.4499 \\
\hline
\end{tabular}

Ea for $\mathrm{k}_{\mathrm{o}}=30.51 \mathrm{kcal} / \mathrm{mole}$

Ea for $\mathrm{k}_{2}=25.74 \mathrm{kcal} / \mathrm{mole}$

Using the $\mathrm{k}_{\mathrm{o}}$ and $\mathrm{k}_{2}$ values for arabinose , fructose and lactose , we calculated the energies of activation graphically (( Figures (A.4) , (B.4) and (C.4) )) for the overall reactions and (( Figures (A.5), (B.5) and (C.5) )) for the bimolecular reactions (table 9$)$.

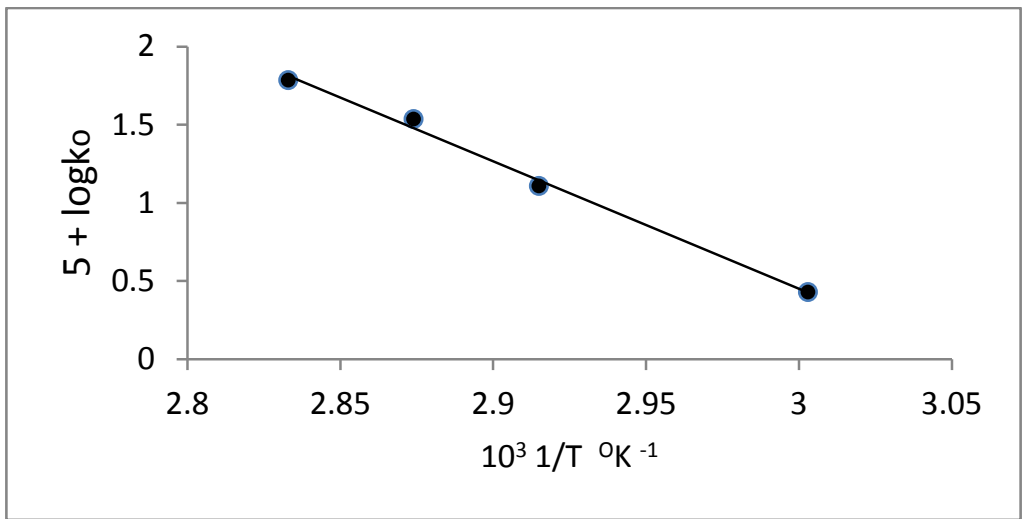

Fig (4.A): Activation energy for arabinose - peroxydisulphate reaction.

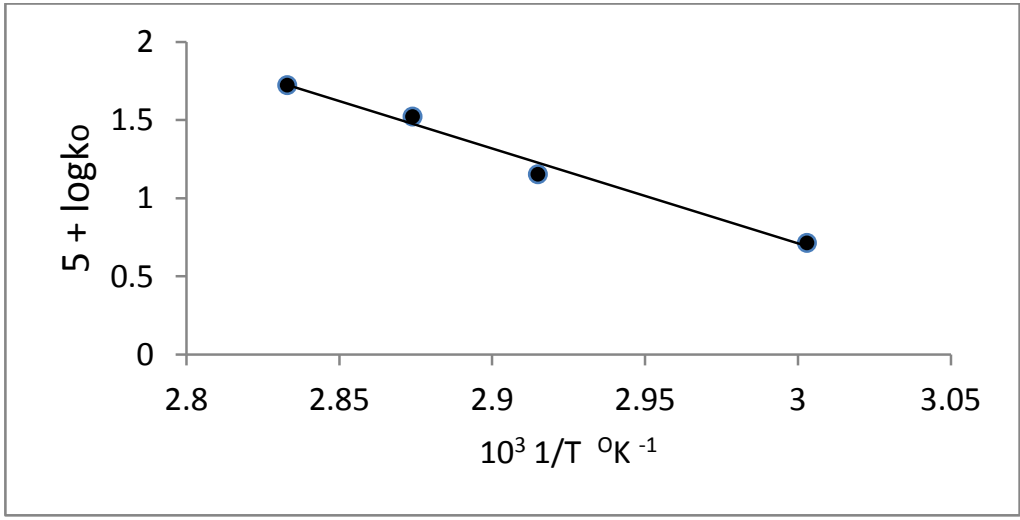

Fig (4.B): Activation energy for fructose - peroxydisulphate reaction

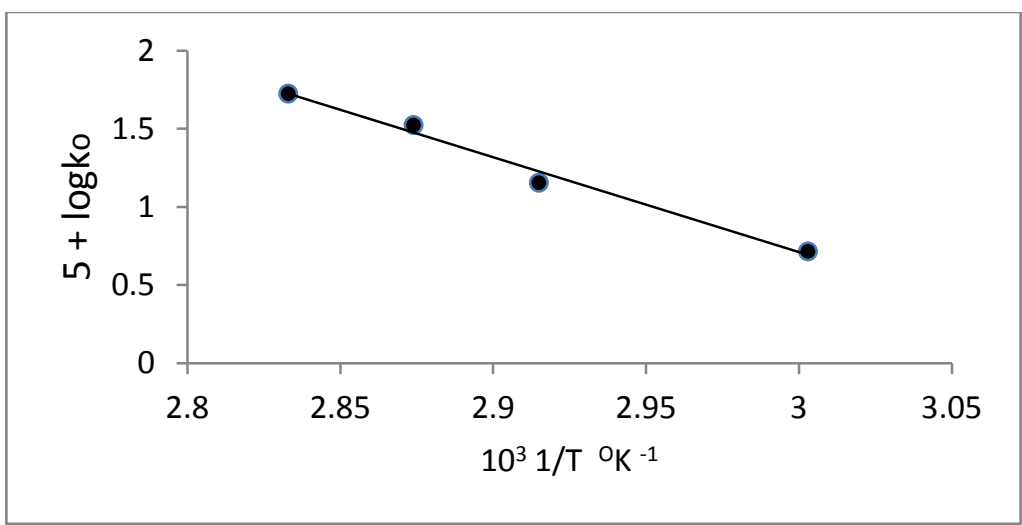

Fig (4.C): Activation energy for lactose - peroxydisulphate reaction 
From $\mathrm{k}_{1}$ the energy of activation of the thermal decomposition found to be $28.7 \mathrm{kcal}$ mole ${ }^{-1}$ [5].The activation energies (table 9) show that the values calculated from $\mathrm{k}_{\mathrm{o}}$ fall between those from the thermal decomposition and the bimolecular reaction. This may take as indirect evidence that the rate laws for such reactions consist of two terms and this supplements our conclusion from kinetic data.

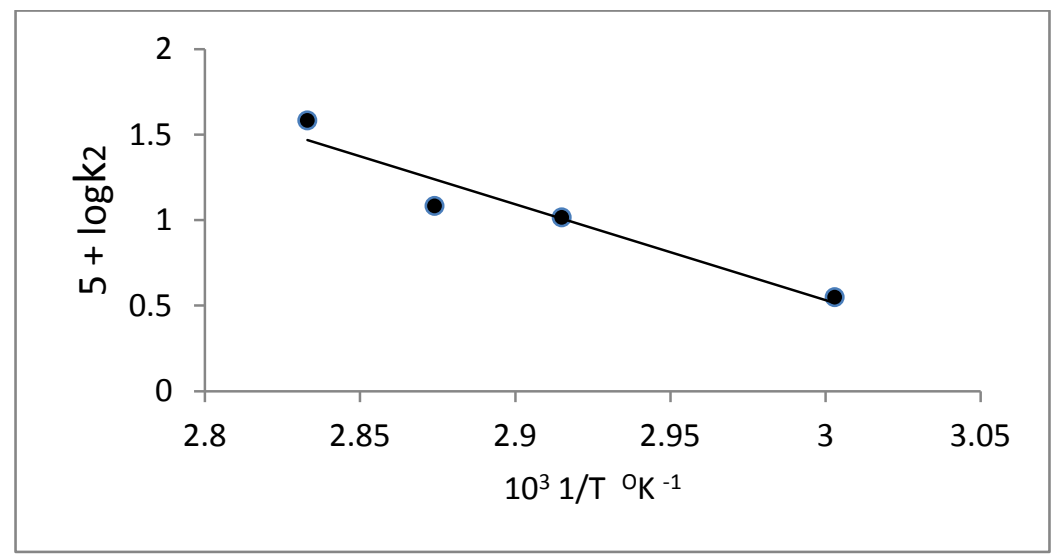

Fig (5.A): Evaluation of the energy of activation of the bimolecular reaction from $\mathrm{K}_{2}$ over the temperature range 60 - $80{ }^{\circ} \mathrm{C}$.(in case of arabinose)

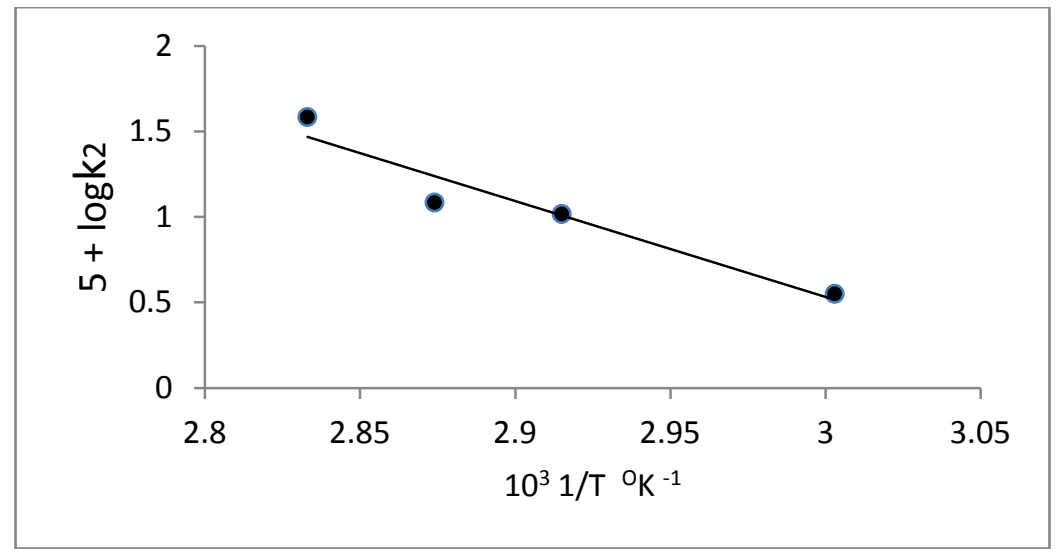

Fig (5.B): Evaluation of the energy of activation of the bimolecular reaction from $\mathrm{K}_{2}$ over the temperature range 60 - $80{ }^{\circ} \mathrm{C}$.(in case of fructose)

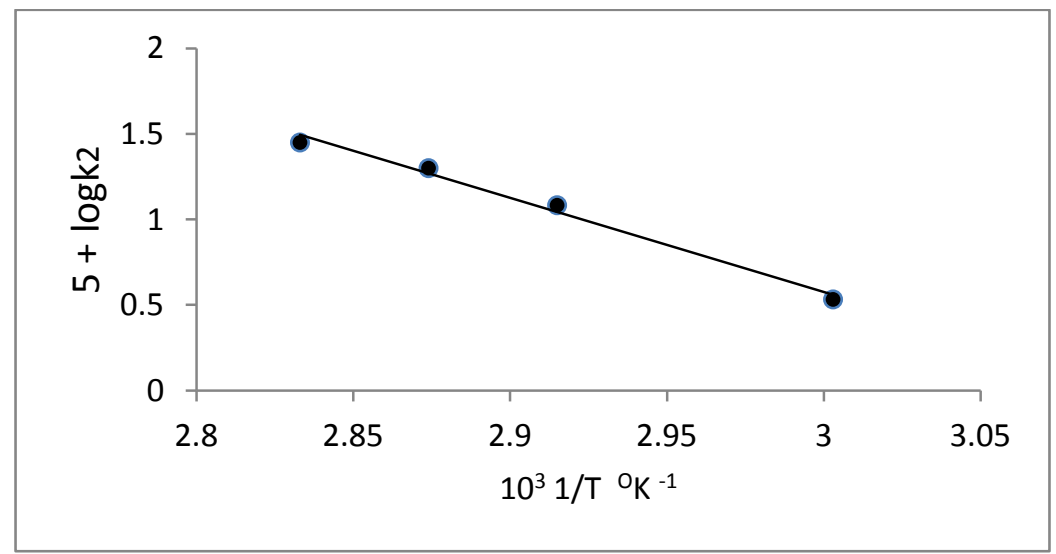

Fig. (C.5): Evaluation of the energy of activation of the bimolecular reaction from $\mathrm{K}_{2}$ over the temperature range 60 - $80^{\circ} \mathrm{C}$.(in case of lactose) 


\section{Conclusion}

A Suggested Mechanism for Arabinose and the General Rate Law:

Since reactions paths of arabinose, fructose and lactose were found rather similar we shall discuss only the mechanism for arabinose reaction and derive its rate law.

Equation (4) shows that the arabinose-peroxydisulphate reaction can be represented by two terms rate law, one of the terms represents the thermal decomposition alone and the second one for the bimolecular reaction, from these two facts, it appears that three paths exist in this reaction and can be represented as follows:

\begin{tabular}{lll}
\hline \multicolumn{3}{c}{ Arabinose + Peroxydisulphate } \\
\hline Path (I) & Path (II) & Path (III) \\
\hline Peroxydisulphate & Aldonic acid & Formaldehyde \\
Thermal decomposition & Aldaric acid & Formic acid \\
\hline
\end{tabular}

Before we proceed forward in discussing the mechanism of this reaction, it was believed that this reaction has the characteristics of chain reaction for the following reasons: [7].

(A) The reaction is first order in peroxydisulphate and fractional order in arabinose concentration.

(B) The rate and the rate constant are sensitive to surface effect as shown in table (7).

(C)The reaction rates are inhibited by the presence of free radical scavengers like allyl acetate as shown in table (8).

The decomposition of peroxydisulphate takes place as a result of the symmetric cleavage of the o - o bond of the peroxydisulphate ion to make two sulphate free radicals $\left(\mathrm{SO}_{4}^{-}\right)$[8]. The sulphate free radical disappear either by reaction with water to produce oxygen or by reaction with arabinose molecule to give free radical which attack peroxydisulphate and this explain the increase in the rate of decomposition of peroxydisulphate by the addition of arabinose.

Path (I) can be represented by the following scheme [9]:

$$
\begin{aligned}
& \mathrm{S}_{2} \mathrm{O}_{8}{ }^{-} \stackrel{\mathrm{K}_{1}}{\longrightarrow} 2 \mathrm{SO}_{4}{ }^{-} \\
& \mathrm{SO}_{4}{ }^{-}+\mathrm{H}_{2} \mathrm{O} \stackrel{\mathrm{K}_{2}}{\longrightarrow} \mathrm{HSO}_{4}{ }^{-}+\mathrm{OH}^{\cdot} \\
& 2 \mathrm{OH}^{\cdot} \longrightarrow \mathrm{H}_{2} \mathrm{O}+1 / 2 \mathrm{O}_{2}
\end{aligned}
$$

Path (II) gives rise to aldonic and aldaric acids. The formation of aldonic acid takes place as a result of direct oxidation of the terminal aldehydic group of the arabinose molecule in the following manner:-

$$
\begin{aligned}
& \mathrm{RCHO}+\mathrm{SO}_{4}^{-} \stackrel{\mathrm{k}_{3}}{\longrightarrow} \mathrm{R}-\mathrm{C}=\mathrm{O}+\mathrm{HSO}_{4}^{-} \\
& \mathrm{RC}=\mathrm{O}+\mathrm{H}_{2} \mathrm{O} \stackrel{\mathrm{k}_{4}}{\longrightarrow} \mathrm{RCOOH}+\mathrm{H} \\
& \mathrm{H} .+\mathrm{OH} \stackrel{\mathrm{k}_{5}}{\longrightarrow} \mathrm{H}_{2} \mathrm{O}
\end{aligned}
$$

The formation of aldaric acid takes place by the oxidation of the primary alcoholic group of the arabinose molecule through an aldehydic stage as follows:

$$
\begin{array}{ll}
\mathrm{RCH}_{2} \mathrm{OH}+\mathrm{OH} \stackrel{\mathrm{k}_{6}}{\longrightarrow} & \mathrm{RCHOH}+\mathrm{H}_{2} \mathrm{O} \\
\mathrm{RCHOH}+\mathrm{S}_{2} \mathrm{O}_{8}=\stackrel{\mathrm{k}_{7}}{\longrightarrow} & \mathrm{RCHO}+\mathrm{HSO}_{4}{ }^{-}+\mathrm{SO}_{4}{ }^{-} \\
\mathrm{RCHOH}+\mathrm{SO}_{4}{ }^{-} \stackrel{\mathrm{k}_{8}}{\longrightarrow} & \mathrm{RCHO}+\mathrm{HSO}_{4}^{-}
\end{array}
$$

Finally we consider the formation of formaldehyde and formic acid by path (III) in which the process of C- C oxidative cleavage proceeds until the arabinose molecule is completely converted to formaldehyde and formic acid, since it is not possible to isolate any product with 2,3 or 4 carbon atoms. The following scheme is designed to show how such products can be formed:-

$$
\begin{aligned}
& \mathrm{CHO} .(\mathrm{CHOH})_{3} \cdot \mathrm{CH} \mathrm{CH}_{2} \mathrm{OH} \rightarrow \mathrm{CHO} .(\mathrm{CHOH})_{3} \mathrm{CHOH}+\mathrm{H}_{2} \mathrm{O} \\
& \mathrm{CHO} \cdot(\mathrm{CHOH})_{3} \cdot \mathrm{CHOH} \rightarrow \mathrm{CHO} \cdot(\mathrm{CHOH})_{3}+\underline{\mathrm{HCHO}} \\
& \mathrm{CHO} \cdot(\mathrm{CHOH})_{3} \cdot+\mathrm{SO}_{4} \rightarrow \mathrm{CHO} \cdot(\mathrm{CHOH})_{2}+\mathrm{CHO}+\mathrm{HSO}_{4} \\
& \mathrm{CHO} \cdot(\mathrm{CHOH})_{2}+\mathrm{SO}_{4} \rightarrow \mathrm{CHO} .(\mathrm{CHOH})+\mathrm{CHO}+\mathrm{HSO}_{4} \\
& \mathrm{CHO} .(\mathrm{CHOH})+\mathrm{SO}_{4} \rightarrow 2 \mathrm{CHO} .+\mathrm{HSO}_{4}
\end{aligned}
$$

This scheme gives rise to four $\mathrm{CHO}$ radicals which give rise to formic acid as follows:-

$$
4 \mathrm{CHO}+4 \mathrm{OH}^{\cdot} \rightarrow \underline{4 \mathrm{HCOOH}}
$$

This scheme should finally leads to the formation of four molecules of formic acid and one molecule of formaldehyde for each molecule of oxidized arabinose. 
In attempting to tie up the proposed mechanism equations (8) to (16) with the experimental rate law equation (5) the problem is simplified by ignoring path (III) and applying the steady state treatment to paths (I) and (II).

At the steady state, the rate of disappearance of peroxydisulphate can be represented by the following equation:

$\frac{-\mathrm{d}\left[\mathrm{S}_{2} \mathrm{O}_{8}=\right]}{\mathrm{dt}}=\mathrm{k}_{1}\left[\mathrm{~S}_{2} \mathrm{O}_{8}=\right]+\mathrm{k}_{7}[\mathrm{RCHOH}]\left[\mathrm{S}_{2} \mathrm{O}_{8}=\right]$

The rate of change in the concentration of the radicals $(\mathrm{RCHOH}),(\mathrm{SO}-4),(\mathrm{OH}),(\mathrm{H})$ and $(\mathrm{R}-\mathrm{C}=\mathrm{O})$ with time equals zero and can be represented by the following equations:

$\frac{\mathrm{d}[\mathrm{RCHOH}]}{\mathrm{dt}}=\mathrm{k}_{6}\left[\mathrm{RCH}_{2} \mathrm{OH}\right][\mathrm{OH}]-\mathrm{k}_{7}[\mathrm{RCHOH}]\left[\mathrm{S}_{2} \mathrm{O}_{8}=\right]-\mathrm{k}_{8}[\mathrm{RCHOH}]\left[\mathrm{SO}_{4}=\right]=0$

$\therefore \mathrm{k}_{6}[$ Arabinose $][\mathrm{OH}]=\mathrm{k}_{7}[\mathrm{RCHOH}]\left[\mathrm{S}_{2} \mathrm{O}_{8}=\right]+\mathrm{k}_{8}[\mathrm{RCHOH}]\left[\mathrm{SO}_{4}{ }^{-}\right]$

$\frac{\mathrm{d}\left[\mathrm{SO}_{4}^{-}\right]}{\mathrm{dt}}=\mathrm{k}_{1}\left[\mathrm{~S}_{2} \mathrm{O}_{8}=\right]-\mathrm{k}_{2}\left[\mathrm{SO}_{4}^{-}\right]\left[\mathrm{H}_{2} \mathrm{O}\right]-\mathrm{k}_{3}[\mathrm{RCHOH}]\left[\mathrm{SO}_{4}=\right]+\mathrm{k}_{7}[\mathrm{RCHOH}]\left[\mathrm{S}_{2} \mathrm{O}_{8}=\right]-\mathrm{k}_{8}\left[\mathrm{RCHOH}^{-}\left[\mathrm{SO}_{4}^{-}\right]=0\right.$

$\mathrm{k}_{1}\left[\mathrm{~S}_{2} \mathrm{O}_{8}=\right]+\mathrm{k}_{7}[\mathrm{RCHOH}]\left[\mathrm{S}_{2} \mathrm{O}_{8}{ }^{=}\right]=\mathrm{k}_{2}\left[\mathrm{SO}_{4}^{-}\right]\left[\mathrm{H}_{2} \mathrm{O}\right]+\mathrm{k}_{3}[$ Arabinose $]\left[\mathrm{SO}_{4}{ }^{-}\right]+\mathrm{k}_{8}[\mathrm{RCHOH}]\left[\mathrm{SO}_{4}{ }^{-}\right]$

$\frac{\mathrm{d}[\mathrm{OH}]}{\mathrm{dt}}=\mathrm{k}_{2}\left[\mathrm{SO}_{4}^{-}\right]\left[\mathrm{H}_{2} \mathrm{O}\right]-\mathrm{k}_{5}[\mathrm{H}][\mathrm{OH}]-\mathrm{k}_{6}\left[\mathrm{RCH}_{2} \mathrm{OH}\right][\mathrm{OH}]=0$

$\mathrm{k}_{2}\left[\mathrm{SO}_{4}^{-}\right]\left[\mathrm{H}_{2} \mathrm{O}\right]=\mathrm{k}_{5}[\mathrm{H}][\mathrm{OH}]+\mathrm{k}_{6}[$ Arabinose $][\mathrm{OH}]$

$\frac{\mathrm{d}[\mathrm{H}]}{\mathrm{dt}}=\mathrm{k}_{4}[\mathrm{R}-\mathrm{C}=\mathrm{O}]\left[\mathrm{H}_{2} \mathrm{O}\right]-\mathrm{k}_{5}[\mathrm{H}][\mathrm{OH}]=0$

$\mathrm{k}_{4}[\mathrm{R}-\mathrm{C}=\mathrm{O}]\left[\mathrm{H}_{2} \mathrm{O}\right]=\mathrm{k}_{5}[\mathrm{H}][\mathrm{OH}]$

$\frac{\mathrm{d}[\mathrm{R}-\mathrm{C}=\mathrm{O}]}{\mathrm{dt}}=\mathrm{k}_{3}[\mathrm{RCHO}]\left[\mathrm{SO}_{4}^{-}\right]-\mathrm{k}_{4}[\mathrm{R}-\mathrm{C}=\mathrm{O}]\left[\mathrm{H}_{2} \mathrm{O}\right]=0$

$\mathrm{k}_{3}[$ Arabinose $]\left[\mathrm{SO}_{4}^{-}\right]=\mathrm{k}_{4}[\mathrm{R}-\mathrm{C}=\mathrm{O}]\left[\mathrm{H}_{2} \mathrm{O}\right]$

From equations (D) and (E) equation (C) can be written as follows:

$\mathrm{k}_{2}\left[\mathrm{SO}_{4}^{-}\right]\left[\mathrm{H}_{2} \mathrm{O}\right]=\mathrm{k}_{3}[$ Arabinose $]\left[\mathrm{SO}_{4}^{-}\right]+\mathrm{k}_{6}[$ Arabinose $][\mathrm{OH}]$

Putting the value of $\mathrm{k}_{6}[$ Arabinose $][\mathrm{OH}]$ from equation $(\mathrm{F})$ into equation $(\mathrm{A})$ we get:

$\mathrm{k}_{2}\left[\mathrm{SO}_{4}^{-}\right]\left[\mathrm{H}_{2} \mathrm{O}\right]-\mathrm{k}_{3}[$ Arabinose $]\left[\mathrm{SO}_{4}^{-}\right]=\mathrm{k}_{7}[\mathrm{RCHOH}]\left[\mathrm{S}_{2} \mathrm{O}_{8}=\right]+\mathrm{k}_{8}[\mathrm{RCHOH}]\left[\mathrm{SO}_{4}^{-}\right]$

Equation $(\mathrm{G})$ can be rearranged to take the form:

$\mathrm{k}_{7}[\mathrm{RCHOH}]\left[\mathrm{S}_{2} \mathrm{O}_{8}=\right]=\left[\mathrm{SO}_{4}^{-}\right]\left\langle\mathrm{k}_{2}\left[\mathrm{H}_{2} \mathrm{O}\right]-\mathrm{k}_{3}[\right.$ Arabinose $\left.]-\mathrm{k}_{8}[\mathrm{RCHOH}]\right\rangle$

Equation (B) can be written as follows:

$\left[\mathrm{S}_{2} \mathrm{O}_{8}=\right]\left(\mathrm{k}_{1}+\mathrm{k}_{7}[\mathrm{RCHOH}]\right)=\left[\mathrm{SO}_{4}{ }^{-}\right]\left\langle\mathrm{k}_{2}\left[\mathrm{H}_{2} \mathrm{O}\right]+\mathrm{k}_{3}[\right.$ Arabinose $\left.]+\mathrm{k}_{8}[\mathrm{RCHOH}]\right\rangle$

On dividing equation (I) by equation $(\mathrm{H})$ we get:

$\frac{\left[\mathrm{S}_{2} \mathrm{O}_{8}=\right]\left(\mathrm{k}_{1}+\mathrm{k}_{7}[\mathrm{RCHOH}]\right)}{\mathrm{k}_{7}[\mathrm{RCHOH}]\left[\mathrm{S}_{2} \mathrm{O}_{8}=\right]}=\frac{\mathrm{k}_{2}\left[\mathrm{H}_{2} \mathrm{O}\right]+\mathrm{k}_{3}[\text { Arabinose }]+\mathrm{k}_{8}[\mathrm{RCHOH}]}{\mathrm{k}_{2}\left[\mathrm{H}_{2} \mathrm{O}\right]-\mathrm{k}_{3}[\text { Arabinose }]-\mathrm{k}_{8}[\mathrm{RCHOH}]}$

By Cross- multiplication of the sides in equation $(\mathrm{J})$ and rearranging we get:

$2 \mathrm{k}_{7} \mathrm{k}_{8}[\mathrm{RCHOH}]^{2}+[\mathrm{RCHOH}]\left[2 \mathrm{k}_{3} \mathrm{k}_{7}[\right.$ Arabinose $\left.]+\mathrm{k}_{1} \mathrm{k}_{8}\right]+\mathrm{k}_{1} \mathrm{k}_{3}[$ Arabinose $]-\mathrm{k}_{1} \mathrm{k}_{2}\left[\mathrm{H}_{2} \mathrm{O}\right]=0$

Or

$[\mathrm{RCHOH}]^{2}+\frac{\left[2 \mathrm{k}_{3} \mathrm{k}_{7}[\text { Arabinose }]+\mathrm{k}_{1} \mathrm{k}_{8}\right][\mathrm{RCHOH}]}{2 \mathrm{k}_{7} \mathrm{k}_{8}}+\frac{\left[\mathrm{k}_{1} \mathrm{k}_{3}[\text { Arabinose }]-\mathrm{k}_{1} \mathrm{k}_{2}\left[\mathrm{H}_{2} \mathrm{O}\right]\right]}{2 \mathrm{k}_{7} \mathrm{k}_{8}}=0$

On solving equation $(\mathrm{L})$ for $[\mathrm{RCHOH}]$, we get:

$[\mathrm{RCHOH}]=\frac{-2 \mathrm{k}_{3} \mathrm{k}_{7}[\text { Arabinose }]+\mathrm{k}_{1} \mathrm{k}_{8}}{2 \mathrm{k}_{7} \mathrm{k}_{8}}+1 / 2 \sqrt{\frac{\left[2 \mathrm{k}_{3} \mathrm{k}_{7}[\text { Arabinose }]+\mathrm{k}_{1} \mathrm{k}_{8}\right]-4 \mathrm{k}_{1} \mathrm{k}_{3}[\text { Arabinose }]-\mathrm{k}_{1} \mathrm{k}_{2}\left[\mathrm{H}_{2} \mathrm{O}\right]}{2 \mathrm{k}_{7} \mathrm{k}_{8}}}$

If we substitute the value of $[\mathrm{RCHOH}]$ in equation (23) for the rate law we get: 


$$
\begin{aligned}
\frac{-\mathrm{d}\left[\mathrm{S}_{2} \mathrm{O}_{8}=\right]}{\mathrm{dt}} & =\mathrm{k}_{1}\left[\mathrm{~S}_{2} \mathrm{O}_{8}=\right]-\mathrm{k}_{7}\left[\frac{2 \mathrm{k}_{3} \mathrm{k}_{7}[\text { Arabinose }]+\mathrm{k}_{1} \mathrm{k}_{8}}{2 \mathrm{k}_{7} \mathrm{k}_{8}}+1 / 2 \sqrt{\left.\frac{\left[2 \mathrm{k}_{3} \mathrm{k}_{7}[\text { Arabinose }]+\mathrm{k}_{1} \mathrm{k}_{8}\right]^{2}}{2 \mathrm{k}_{7} \mathrm{k}_{8}}-\frac{4 \mathrm{k}_{1} \mathrm{k}_{3}[\text { Arabinose }]-\mathrm{k}_{1} \mathrm{k}_{2}\left[\mathrm{H}_{2} \mathrm{O}\right]}{2 \mathrm{k}_{7} \mathrm{k}_{8}}\right]\left[\mathrm{S}_{2} \mathrm{O}_{8}=\right]}\right. \\
& =\mathrm{k}_{\mathrm{O}}\left[\mathrm{S}_{2} \mathrm{O}_{8}=\right]
\end{aligned}
$$

Where,

$\mathrm{k}_{\mathrm{O}}=\mathrm{k}_{1}-\mathrm{k}_{7}\left[\frac{2 \mathrm{k}_{3} \mathrm{k}_{7}[\text { Arabinose }]+\mathrm{k}_{1} \mathrm{k}_{8}}{2 \mathrm{k}_{7} \mathrm{k}_{8}}+1 / 2 \sqrt{\frac{\left[2 \mathrm{k}_{3} \mathrm{k}_{7}[\text { Arabinose }]+\mathrm{k}_{1} \mathrm{k}_{8}\right]^{2}}{2 \mathrm{k}_{7} \mathrm{k}_{8}}-\frac{4 \mathrm{k}_{1} \mathrm{k}_{3}[\text { Arabinose }]-\mathrm{k}_{1} \mathrm{k}_{2}\left[\mathrm{H}_{2} \mathrm{O}\right]}{2 \mathrm{k}_{7} \mathrm{k}_{8}}}\right]$

\section{References}

[1] Wilmorth, W. K., Haim, A., " Peroxide Reaction Mechanism" New. York, Jon Wiley and Sons Ins, NY (1962), p175.

[2] Wood, J.K, Walker, N.J, J. Chem. Soc., (1914), p1131 http://dx.doi.org/10.1039/ct9140501131.

[3] Vasudeva, W.C., Ph.D thesis, Fac.of Science, U. Of K (1969).

[4] Findlay, A. " Practical Physical Chemistry" Longmans, Green and Co. Ltd, London, (1961), p206.

[5] A/mageed, M.J., Ph.D thesis, Fac.of Science, U. Of K (2001).

[6] Benzvi, E., Allen, T., J. Amer. Chem. Soc. Vol .83, (1961), p4352. http://dx.doi.org/10.1021/ja01482a013.

[7] Dainton, F. S. "Chain Reactions" Methuen and CO.Ltd. London, John Wiley and Sons. Inc. New York (1956), P29.

[8] Kolthoff, I.M, Miller, I.K, J. Amer.Chem. Soc, Vol.73, (1951), p3055. http://dx.doi.org/10.1021/ja01151a024.

[9] Bartlett, P.D,Cotman, J.D., J. Amer.Chem. Soc., Vol.71, (1949), 1419. http://dx.doi.org/10.1021/ja01172a078. 